\title{
Crystal Structure and Ionic Conductivity Study of Ni- Doped BSCF Cathode for Low Temperature SOFCS
}

\author{
Suman Kumar Burnwal and P. Kistaiah
}

\begin{abstract}
Nickel doped BSCF $\left(\mathrm{Ba}_{0.5} \mathrm{Sr}_{0.5} \mathrm{Co}_{1-x} \mathrm{Fe}_{0.6} \mathrm{Ni}_{x} \mathrm{O}_{3-\delta}\right.$ (BSCFNi); $x=0.05,0.1,0.15$, and 0.2) cathode materials were synthesized using sol-gel citrate method for low temperature $\left(300-500^{\circ} \mathrm{C}\right)$ Solid Oxide Fuel Cell (SOFC) application. The nanopowders of BSCFNi were then calcinated at various temperatures in the range of $600-1000^{\circ} \mathrm{C}$. The nanopowders were characterized using X-ray diffraction (XRD), scanning electron microscope (SEM) and differential scanning calorimeter (DSC). A cubic perovskite structure was observed in the X-ray diffraction measurements. The average crystallite size of the nanopowder obtained varies between 40-60 $\mathrm{nm}$. $D S C$ result, measured in the temperature range of $200-600^{\circ} \mathrm{C}$, shows no phase transition. Ionic conductivity of the BSCFNi for varying concentration of nickel was measured in the temperature range of $200{ }^{\circ} \mathrm{C}$ to $500^{\circ} \mathrm{C}$. An emphasis is made on the effect of Ni doping on these properties.
\end{abstract}

Keywords--- SOFC, Nanopowders, Cathode, Ionic Conductivity

\section{INTRODUCTION}

$\mathrm{T}$ HE use of Solid Oxide Fuel Cells (SOFCs), which represent the cleanest, most efficient and versatile technologies for chemical-to-electrical energy conversion, could significantly reduce the production of greenhouse gases while minimizing pollutant emission. SOFC technology faces major problems, on the way to commercialization, such as long term stability, production cost and high operating temperature. On the one hand, high temperatures limit the choice of materials and complicate the production process, degradation phenomena on the other hand, which restrict the life time of SOFC, are more problematic at higher temperatures. One important goal in SOFC research is therefore the search for cathode materials which offer a sufficient electrochemical performance already at intermediate temperatures (873-1073 K). Design requirements for cathode are: high electronic conductivity and ionic conductivity, moderate thermal expansion coefficient with stability similar to other SOFC materials (usually the electrolyte), large triple phase boundary, low area specific resistance (ASR), catalyze the dissociation of

Suman Kumar Burnwal, Assistant Professor, CVR College of Engineering, Ibrahimpatan, Hyderabad, India.

P. Kistaiah, Professor \& HOD, Dept. of Physics, Osmania University, Hyderabad, India. E-mail: bheeshm06@gmail.com oxygen and low electrode resistance [1, 2]. Most of these characteristics are possessed by the MIEC and its composite materials.

Reduction of the operation temperature in SOFC system has a vital importance in reducing the cost of the system, which is an inevitable path for the commercialization of this technology. A key obstacle to reduced temperature operation of SOFC is the poor catalytic activity of traditional cathode materials like Lanthanum Strontium Mangnites (LSM) for electrochemical reduction of oxygen in the temperature range of $300-500^{\circ} \mathrm{C}$. However, mixed electronic and ionic conductors (MIEC), such as $\mathrm{La}_{1-\mathrm{x}} \mathrm{Sr}_{\mathrm{x}} \mathrm{Co}_{1-\mathrm{y}} \mathrm{Fe}_{\mathrm{y}} \mathrm{O}_{3-\delta}$ (LSCF) and $\mathrm{Ba}_{1-\mathrm{x}} \mathrm{Sr}_{\mathrm{x}} \mathrm{Co}_{1-\mathrm{y}} \mathrm{Fe}_{\mathrm{y}} \mathrm{O}_{3-\delta}$ (BSCF), attract much attention as cathodes due to their unique ability to improve SOFC performance which depends on the oxygen incorporation reaction.

MIEC perovskite oxide $\left(\mathrm{ABO}_{3}\right)$ is widely considered as an ideal cathode material for low and intermediate temperature solid oxide fuel cell. BSCF perovskite is a new material with high catalytic activity, which means that oxygen atoms can be oxidized as ions as efficient as possible i.e., good oxygen permeability, and it shows an excellent performance as cathode on ceria electrolyte in low temperature range from 400-600 ${ }^{\circ} \mathrm{C}$ [3]. According to E. Bucher BSCF is well known to transport a significant amount of oxygen anions via oxygen vacancies, the ionic conductivity value found is $0.018 \mathrm{~S} / \mathrm{cm}$ at $700{ }^{\circ} \mathrm{C}[4]$.

In the present work, the emphasis is put on $\mathrm{Ni}$ doped BSCF perovskite i.e., $\mathrm{Ba}_{0.5} \mathrm{Sr}_{0.5} \mathrm{Co}_{1-x} \mathrm{Fe}_{0.6} \mathrm{Ni}_{x} \mathrm{O}_{3-\delta}$ (BSCFNi) for low temperature $\left(200-500{ }^{\circ} \mathrm{C}\right)$ application as cathode of SOFC. The paper presents the effect of porosity, low sintering temperature results in high porosity, on the ionic conductivity of the samples. From the study it is found that BSCFNi with Ni concentration $x=0.15$ shows the highest ionic conductivity.

\section{EXPERIMENTAL WORK}

Citrate method is used for the preparation of the samples of $\mathrm{Ba}_{0.5} \mathrm{Sr}_{0.5} \mathrm{Co}_{\mathrm{x}} \mathrm{Fe}_{0.6} \mathrm{Ni}_{1-\mathrm{x}} \mathrm{O}_{3-\delta}$ (BSCFNi) powder in the present work. Initially, the nitrate salts of Barium $\left[\mathrm{Ba}\left(\mathrm{NO}_{3}\right)_{2}\right]$; Strontium $\quad\left[\mathrm{Sr}\left(\mathrm{NO}_{3}\right)_{2}\right] ;$ Cobalt $\left[\mathrm{Co}\left(\mathrm{NO}_{3}\right)_{2} \cdot 6 \mathrm{H}_{2} \mathrm{O}\right]$; Iron $\left[\mathrm{Fe}\left(\mathrm{NO}_{3}\right)_{3} .9 \mathrm{H}_{2} \mathrm{O}\right]$; and Nickel $\left[\mathrm{Ni}\left(\mathrm{NO}_{3}\right)_{2} \cdot 6 \mathrm{H}_{2} \mathrm{O}\right]$ are mixed in their stoichiometric ratio in double distilled water and stirred it for hours till the complete salts gets dissolved. To this solution citric acid is added in the ratio of 1:1 and again stirred for hours till homogeneous solution is obtained. The $\mathrm{pH}$ of the above solution is adjusted to 7 by adding ammonia solution 
and heated for hours at $85{ }^{\circ} \mathrm{C}$ and the sol is changed into gel. The gel formed is heated at $120{ }^{\circ} \mathrm{C}$ for $8 \mathrm{hrs}$, resulting in the formation of the black precursor powder of BSCFNi.

To increase the homogeneity of the powder, it is subjected to calcination at $1000{ }^{\circ} \mathrm{C}$ for $4 \mathrm{hrs}$, followed by grinding in an agate mortar for hours. Pellets of BSCFNi, having a diameter of $13 \mathrm{~mm}$ and thickness of $2-3 \mathrm{~mm}$, are prepared by pressing the powder uniaxially at a pressure of $10 \mathrm{~kg} \mathrm{~m}^{-1} \mathrm{sec}^{-2}$. The pellets are then dried at $100{ }^{\circ} \mathrm{C}$ for 2 hours in a closed container.

The crystal structures and lattice parameters of the BSCFNi perovskite are determined by means of X-ray diffraction (X-PERT PRO with $\mathrm{Cu}-\mathrm{K} \alpha$ radiation) analysis. Morphology of the calcined powder is observed with a scanning electron microscope. Differential Scanning Calorimeter (DSC) measurement, carried out in the temperature range of $300-600{ }^{\circ} \mathrm{C}$, shows no phase transition. The electrochemical behaviour of the $\mathrm{Ba}_{0.5} \mathrm{Sr}_{0.5} \mathrm{Co}_{\mathrm{x}} \mathrm{Fe}_{0.6} \mathrm{Ni}_{1}$ ${ }_{\mathrm{x}} \mathrm{O}_{3-\delta}$ for varying composition of $\mathrm{Ni}$ was evaluated with electrochemical impedance spectroscopy (EIS) in the frequency range of $1 \mathrm{~Hz}$ to $1 \mathrm{MHz}$ and at signal amplitude of 5 $\mathrm{mV}$ at $50{ }^{\circ} \mathrm{C}$ temperature intervals from $200{ }^{\circ} \mathrm{C}$ to $500{ }^{\circ} \mathrm{C}$ under an open circuit state.

\section{RESULTS AND DISCUSSION}

\section{A. Structural Study}

BSCFNi calcined powders with various levels of $\mathrm{Ni}$ doping exhibit well-cystallised XRD patterns measured in the Bragg angle range of $20^{\circ} \leq 2 \theta \leq 80^{\circ}$ as shown in figure- 1 . With increase in the $\mathrm{Ni}$ concentration, the pattern peak shifts towards high angle direction which corresponds to the lattice shrinkage. The peaks are indexed on the basis of a cubic perovskite phase with the space group Pm3m (221) [5]. It has been reported that the synthesis of the sample through citric route forms undesired secondary phases of Barium and Strontium due to the poor distribution of the alkaline-earth metal (for example, $\mathrm{Sr}^{2+}$ ) in the solution caused by the relatively weak chelation between $\mathrm{Sr}^{2+}$ and carboxylate ligands [6-8]. However, these undesired secondary phases can be removed by calcining at $1000{ }^{\circ} \mathrm{C}$. Thus the synthesised powders are calcined at $1000^{\circ} \mathrm{C}$ to increase the homogeneity of the powder that could be observed from the X-ray diffraction pattern showed in figure-1.

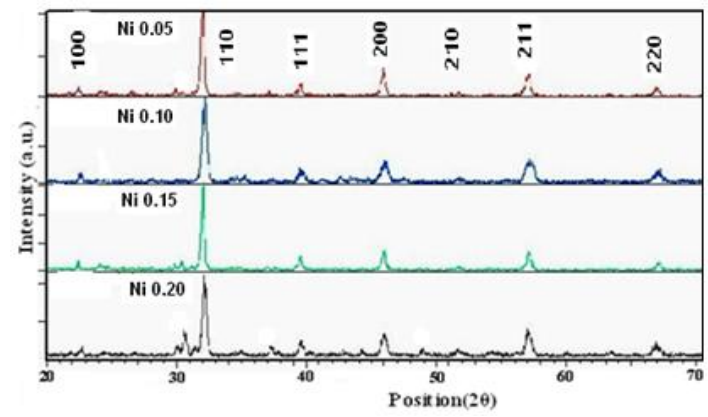

Figure-1: XRD Patterns of $\mathrm{Ba}_{0.5} \mathrm{Sr}_{0.5} \mathrm{Co}_{\mathrm{x}} \mathrm{Fe}_{0.6} \mathrm{Ni}_{1-\mathrm{x}} \mathrm{O}_{3-\delta}(0.05 \leq$ $\mathrm{x} \leq 0.2$ ) Samples
Table 1: Room Temperature XRD Data for

$\mathrm{Ba}_{0.5} \mathrm{Sr}_{0.5} \mathrm{Co}_{\mathrm{x}} \mathrm{Fe}_{0.6} \mathrm{Ni}_{1-\mathrm{x}} \mathrm{O}_{3-\delta}$ samples

\begin{tabular}{|c|c|c|c|}
\hline $\begin{array}{c}\text { Ni- dopant } \\
(\mathrm{x})\end{array}$ & $\begin{array}{c}\text { Lattice } \\
\text { Constant } \\
(\AA)\end{array}$ & $\begin{array}{c}\text { X-ray density } \\
\left(\mathrm{gm} / \mathrm{cm}^{3}\right)\end{array}$ & $\begin{array}{c}\% \\
\text { Porosity }\end{array}$ \\
\hline 0.05 & 3.9551 & 5.838 & 30.41 \\
\hline 0.10 & 3.9471 & 5.873 & 29.97 \\
\hline 0.15 & 3.9407 & 5.901 & 29.63 \\
\hline 0.20 & 3.9368 & 5.919 & 29.26 \\
\hline
\end{tabular}

The lattice parameters of BSCFNi are calculated by least square programme using the whole pattern matching. The calculated lattice parameters, X-ray density and porosity (\%) are shown in Table-1. It is observed from the table that the lattice parameter decreases with increase in $\mathrm{Ni}$ concentration. It is expected that the the substitution of the smaller $\mathrm{Ni}^{3+}(0.74$ $\AA$ ) cation for $\mathrm{Co}^{3+}(0.75 \AA)$ cation of the B-site with $\mathrm{Fe}$ in $4+$ state $\left(\mathrm{Fe}^{4+}\right.$ ionic radii $=0.73 \AA$ ) caused a little shrinkage in the lattice and results in the formation of oxygen vacancies [9]. The average crystallite size of BSCFNi powders as calculated by Debye-Scherrer's equation was $50 \mathrm{~nm}$. Also the high porosity of the BSCFNi pellets obtained is due to low sintering tempertaure.

Scanning Electron Micrographs of $\mathrm{Ba}_{0.5} \mathrm{Sr}_{0.5} \mathrm{Co}_{\mathrm{x}} \mathrm{Fe}_{0.6} \mathrm{Ni}_{1-}$ ${ }_{\mathrm{x}} \mathrm{O}_{3-\delta}$ powder calcined at $1000{ }^{\circ} \mathrm{C}$ for $4 \mathrm{hrs}$ are shown in figure2 . The presence of highly porous spherical particles with a nano-metric grain size, varying between 1 to $2 \mu \mathrm{m}$, is observed in the morphology of powders obtained in this work, which resembled the typical cathode structure for SOFC.

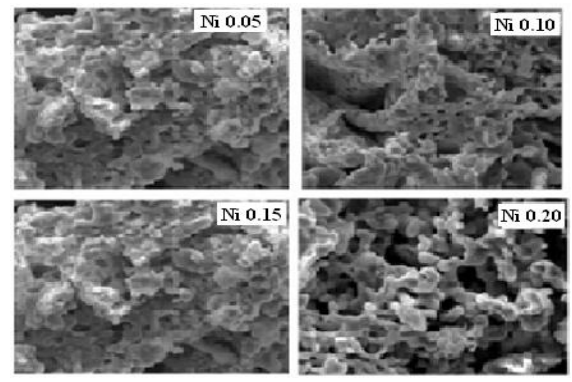

Figure 2: SEM Images of the $\mathrm{Ba}_{0.5} \mathrm{Sr}_{0.5} \mathrm{Co}_{\mathrm{x}} \mathrm{Fe}_{0.6} \mathrm{Ni}_{1-\mathrm{x}} \mathrm{O}_{3-\delta}(0.05$ $\leq \mathrm{x} \leq 0.2)$ Powder

The result of a DSC experiment is a curve of heat flux versus temperature measured for $\mathrm{Ni}-0.15$ and $\mathrm{Ni}-0.2$ concentration, shown in figure-(3). The sample undergoes exothermic processes, such as Crystallisation, shows less heat required to raise the sample temperature. This may be due to the increase in the relative density of the $\mathrm{Ba}_{0.5} \mathrm{Sr}_{0.5} \mathrm{Co}_{\mathrm{x}} \mathrm{Fe}_{0.6} \mathrm{Ni}_{1-\mathrm{x}} \mathrm{O}_{3-\delta}$ with increase in the nickel concentration. It was also observed from the figure-3 that no phase transition takes place measured for the calcined powders (calcinations temperature $1000{ }^{\circ} \mathrm{C}$ ) of BSCFNi in the temperature range of 200 to $600{ }^{\circ} \mathrm{C}$. 


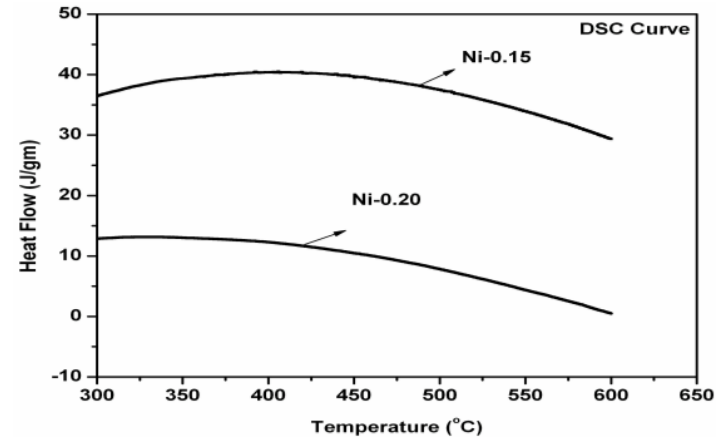

Figure 3: DSC Curve of BSCFNi Nanopowders for $\mathrm{x}=0.15$ and $\mathrm{x}=0.2$ Concentration

\section{B. Ionic Conductivity Measurement}

The ionic conductivity of the cathode electrode is calculated as a characteristic measure for the MIEC cathode performance. Figure-4 shows the variation of ionic conductivity of $\mathrm{Ba}_{0.5} \mathrm{Sr}_{0.5} \mathrm{Co}_{\mathrm{x}} \mathrm{Fe}_{0.6} \mathrm{Ni}_{1-\mathrm{x}} \mathrm{O}_{3-\delta} \quad(0.05 \leq \mathrm{x} \leq 0.2)$ measured in the temperature range of $200-500{ }^{\circ} \mathrm{C}$ for the pellets of area $1.327 \mathrm{~cm}^{2}$.

The ionic conductivity $\left(\sigma_{\text {ion }}\right)$ in the cathode takes place at low frequencies and it increases with increase in the temperature as expected. The ionic conductivity values of the BSCFNi measured for $0.05 \leq \mathrm{x} \leq 0.2$ is shown in table- 2 . It is observed from the table that the ionic conductivity $\left(\sigma_{\text {ion }}\right)$ value increases for $x=0.05$ to 0.15 except for $x=0.2$. The ionic conductivity $\left(\sigma_{\text {ion }}\right)$ value is higher for Ni concentration $\mathrm{x}=0.15$ compared to other $\mathrm{Ni}$ dopant concentration. The high ionic conductivity is due to the better catalytic behaviour of BSCFNi and the significant open porosity which enable oxygen reduction not only on the surface but also in the entire volume of the electrode.

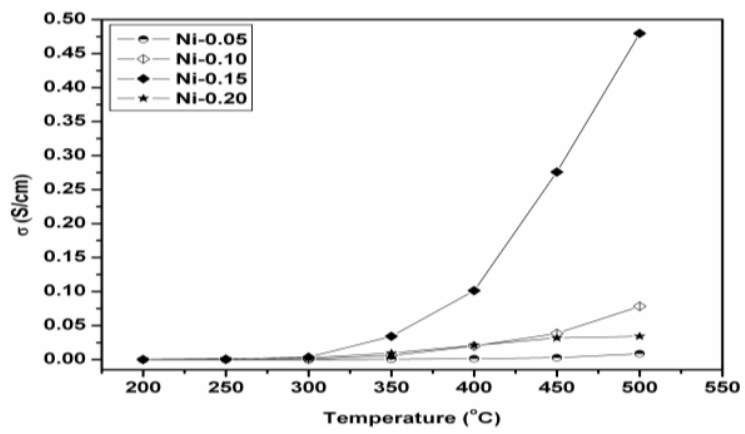

Figure 4: Ionic Conductivity for $\mathrm{Ba}_{0.5} \mathrm{Sr}_{0.5} \mathrm{Co}_{\mathrm{x}} \mathrm{Fe}_{0.6} \mathrm{Ni}_{1-\mathrm{x}} \mathrm{O}_{3-\delta}$ $(0.05 \leq \mathrm{x} \leq 0.2)$

Table 2: Ionic Conductivity Data for $\mathrm{Ba}_{0.5} \mathrm{Sr}_{0.5} \mathrm{Co}_{\mathrm{x}} \mathrm{Fe}_{0.6} \mathrm{Ni}_{1-\mathrm{x}} \mathrm{O}_{3-}$ ${ }_{\delta}$ Samples $(0.05 \leq \mathrm{x} \leq 0.20)$ Measured at 400 and $500{ }^{\circ} \mathrm{C}$

\begin{tabular}{|c|c|c|}
\hline $\begin{array}{c}\text { Ni- } \\
\text { Concentration } \\
(\mathrm{x})\end{array}$ & \multicolumn{2}{|c|}{ Ionic Conductivity $\left(\mathrm{S}^{-\mathrm{cm}^{-1}}\right)$} \\
\cline { 2 - 3 } & $400{ }^{\circ} \mathrm{C}$ & $500{ }^{\circ} \mathrm{C}$ \\
\hline 0.05 & 0.0013 & 0.0086 \\
\hline 0.10 & 0.0199 & 0.0784 \\
\hline 0.15 & 0.1014 & 0.5257 \\
\hline 0.20 & 0.0209 & 0.0343 \\
\hline
\end{tabular}

The oxygen reduction behaviour could be explained in terms of the lattice shrinkage. The lattice shrinkage in the samples of BSCFNi increases with increase in the nickel concentration as the smaller $\mathrm{Ni}^{3+}(0.74 \AA)$ cation replaces the $\mathrm{Co}^{3+}(0.75 \AA$ ) $)$ cation at the B-site $(\mathrm{Fe}$ is in +4 state $)$ of $\mathrm{ABO}_{3}$ perovskite structure. The average oxidation state of the B-site is 3.333 which lead to the formation of oxygen vacancies in the lattice to maintain the electrical neutrality of the perovskite on account of the charge compensation. The formation of oxygen vacancies increases with increase in the $\mathrm{Ni}$ concentration in BSCFNi. It is known that the oxygen vacancies on the electrode surface or in the electrode provide the reaction site for the reduction of molecular oxygen and the pass way for the diffusion of reduced oxygen ions [10-12]. Therefore, the oxygen vacancies concentration of the cathode material should play an important role on the change of the ionic conductivity due to the oxygen adsorption or desorption and the oxygen ions diffusion in the electrode.

According to Kharton, the high ionic conductivity of BSCFNi perovskite with increase in the Ni content, substituted in place of $\mathrm{Co}$, could be attributed to the weaker $\mathrm{Ni}-\mathrm{O}$ bond strength compared to $\mathrm{Co}-\mathrm{O}$ bond [13]. The decrease in the $\sigma_{\text {ion }}$ for $\mathrm{Ni}-0.20$ may be due to the $\mathrm{Ni}$ dopant concentration exceeding a certain value called percolation limit, at which electronic conduction becomes predominant [14].

In this work, BSCFNi with $\mathrm{Ni}$ concentration of $\mathrm{x}=0.15$ has the highest ionic conductivity value of $0.5257 \mathrm{~S} / \mathrm{cm}$ at $500{ }^{\circ} \mathrm{C}$ compared to the reported $\sigma_{\text {ion }}$ values of BSCF which were obtained to be $0.006 \mathrm{~S} / \mathrm{cm}$ at $600{ }^{\circ} \mathrm{C}$ and $0.018 \mathrm{~S} / \mathrm{cm}$ at $700{ }^{\circ} \mathrm{C}$ [15]. Other reported ionic conductivity results are $\mathrm{La}_{0.6} \mathrm{Sr}_{0.4} \mathrm{CoO}_{3}[16,17], \mathrm{La}_{0.6} \mathrm{Sr}_{0.4} \mathrm{Co}_{0.8} \mathrm{Fe}_{0.2} \mathrm{O}_{3}$ [18, 19] and $\mathrm{Sr}_{0.9} \mathrm{Ce}_{0.1} \mathrm{Fe}_{0.8} \mathrm{Ni}_{0.2} \mathrm{O}_{3}$ [16] whose $\sigma_{\text {ion }}$ values are $0.22 \mathrm{~S} / \mathrm{cm}$, $0.058 \mathrm{~S} / \mathrm{cm}$ and $0.04 \mathrm{~S} / \mathrm{cm}$ obtained at $800{ }^{\circ} \mathrm{C}$ respectively.

\section{CONCLUSION}

BSCF with varying Nickel contents $\left(\mathrm{Ba}_{0.5} \mathrm{Sr}_{0.5} \mathrm{Co}_{\mathrm{x}} \mathrm{Fe}_{0.6} \mathrm{Ni}_{1-}\right.$ ${ }_{\mathrm{x}} \mathrm{O}_{3-\delta}, \mathrm{x}=0.05,0.1,0.15$ and 0.2 ) are prepared using sol-gel citrate method. The samples are calcined at $1000^{\circ} \mathrm{C}$ to remove any secondary phases to yield well crystallized BSCFNi powders. The effect of Nickel doping (Ni substitution for Cobalt in BSCF) on the microstructure, heat flux (obtained from DSC) and the ionic conductivity $\left(\sigma_{\text {ion }}\right)$ was investigated and it was found that $\mathrm{Ni}$ doping with $\mathrm{x}=0.15$ showed the better result. Thus the BSCFNi with optimum Nickel doping level can be a good candidate as cathodes for low temperature SOFCs application.

\section{ACKNOWLEDGEMENT}

I would like to thank the management of CVR College of Engineering for providing me the facility to prepare the samples of my research work in the Engineering Physics Laboratory.

\section{REFERENCES}

[1] E. Maguire, B. Gharbage, F.M.B. Marques and J.A. Labrincha; Solid State Ionics, 127, 329-335, 2000.

[2] S.C. Singhal; Solid State Ionics 135, 305-313, 2000.

[3] S.J Skinner; Fuel Cells Bull; 33, 2001. 
[4] E. Bucher, A. Egger, P. Ried, W. Sitte and P. Holtappels, Sold State Ionics 179, 1032, 2008.

[5] H. Koster and F H B Mertins, Powder Diffraction 18, 56-59, 2003.

[6] J. Pena-Martinez, D. Marrero-Lopez, J.C. Ruiz- Morales, P. Nunez, C. Sanchez-Bautista and Dos Santos-Garcia, International Journal of Hydrogen Energy 34, 9486-95, 2009.

[7] J. Pena-Martinez, D. Marrero-Lopez, J.C. Ruiz-Morales, B.E. Buergler, P. Nunez and L.J. Gauckler, Solid State Ionics 177, 2143-7, 2006.

[8] K. Huang, J. Wan and J.B. Goodenough, Journal of Material Science, 36, 1093-8, 2001.

[9] Wei Zhou, Ran Ran, Zongping Shao, Journal of Power Sources 192, 231-246, 2009.

[10] T. Ishihara, T. Kudo, H. Matsuda and Y. Takita, J. of Electrochemical Society, 142, 1519, 1995.

[11] S. Kim, S. Wang, X. Chen, Y.L. Yang, N. Wu, A. Ignatiev, A.J. Jacobson and B. Abeles, J. of Electrochemical Society, 147, 2398, 2000.

[12] T. Horita, K. Yamaji, N. Sakai, H. Yokokawa, T. Kawada and T. Kato, Solid State Ionics 127, 55, 2000.

[13] V.V. Kharton et. al., Solid State Ionics 132, 119-130, 2000.

[14] V.V. Kharton, A.A. Yaremchenko and E.N. Naumovich, J. Solid State Electrochem. 3, 303,1999.

[15] Zhou Wei, Ran Ran and Zongping Shao, Journal of Power Sources 192, 231-246, 2009.

[16] H. Ullmann, N. Trofimenko, F. Tietz, D. Stöver and A. AhmadKhanlou, Solid State Ionics 138, 79, 2000.

[17] Y. Teraoka, H.M. Zhang, K. Okamoto and N. Yamazoe, Mater Res Bull 23, 51, 1988.

[18] A. Petric, P. Huang and F. Tietz, Solid State Ionics 135, 719, 2000.

[19] Y. Teraoka, T. Nobunaga, K. Okamoto, N. Miura and N. Yamazoe, Solid State Ionics 48, 207, 1991. 